\title{
The effect of passage and iron on the virulence of Pseudomonas aeruginosa
}

\author{
CHRISTINE M. FORSBERG AND J. J. BULLEN \\ From the National Institute for Medical Research, Mill Hill, London
}

SYNOPSIS The factors concerned with the virulence of Pseudomonas aeruginosa are relatively labile and can be enhanced by passage. Virulence is further enhanced if the serum transferrin of the host is saturated with iron. These results draw attention to the possible serious consequences of accidental passage in hospitals, and focus attention on the importance of transferrin as a factor in non-specific resistance.

Since the advent of antibiotic therapy Pseudomonas aeruginosa has been increasingly incriminated as a cause of serious infection in hospitals, especially among postoperative patients (Forkner, Frei, Edgcomb, and Utz, 1958; Tinne, Gordon, Bain, and Mackey, 1967; Lowbury, Thom, Lilly, Babb, and Whittall, 1970), the chronically sick (Williams, Williams, and Hyams, 1960; Feingold, 1970), and those suffering from burns (Rabin, Graber, Vogel, Finkelstein, and Tumbusch, 1961) or receiving immunosuppressive treatment (Mowbray, Cohen, Doak, Kenyon, Owen, Percival, Porter, and Peart, 1965).

Very little is known about the factors concerned with the virulence of this organism. Klyhn and Gorrill (1967) studied a large number of strains isolated from hospital patients and found that virulence for mice could not be correlated with any characteristic, apart from the fact that the more virulent strains appeared to produce larger colonies than the rest. Carney and Jones (1968) studied culture filtrates from two virulent and one avirulent strain but found little difference in biological properties apart from the speed of digestion of a number of different substrates and the quantity of enzyme produced. However, the avirulent strain did appear to lack one antigen possessed by the virulent strains.

Recent investigators have drawn attention to the ability of various iron compounds to enhance the virulence of Escherichia coli (Bullen, Leigh, and Rogers, 1968) and to abolish passive immunity to Pasteurella septica (Bullen and Rogers, 1969) and Clostridium welchii type A (Rogers, Bullen, and Cushnie, 1970). It is suggested that the iron-binding Received for publication 20 May 1971. protein transferrin may play an important role in non-specific resistance and that bacterial iron metabolism is closely involved in pathogenicity.

The work reported here has shown that the virulence of Ps. aeruginosa for mice can be enhanced by passage. In addition it has been found that the injection of iron compounds leads to a further enhancement of virulence. With the more recent passages this enhancement is so great that less than 10 organisms injected with iron produce a fatal infection in mice.

\section{Materials and Methods}

\section{PS. AERUGINOSA}

A strain of Ps. aeruginosa recently isolated from a hospital patient was obtained from Dr D. Martin, Cross-Infection Reference Laboratory, Colindale. This strain gave smooth, mucoid, opaque colonies on fresh blood agar plates, produced pyocyanin in large quantities, and was carrying a lysogenic phage. Antibiotic sensitivity tests showed that it was resistant to ampicillin (25 units/ml), kanamycin (30 units $/ \mathrm{ml})$, chloramphenicol (50 units $/ \mathrm{ml})$, and tetracycline (50 units/ml), and sensitive to colistin methane sulphonate ( 200 units/ml) and streptomycin (25 units/ml). Carbenicillin and gentamicin were not tried.

STORAGE AND CULTIVATION

It was quickly found that virulence for mice was readily lost if the strain was stored on nutrient agar slants at $4^{\circ} \mathrm{C}$ or serially subcultured on fresh blood agar plates. Virulence was preserved for three to four months by storing the organism in egg-brain-liverbroth medium (homogenized bovine brain (250 g) 
plus 1 egg yolk, $p \mathrm{H}$ adjusted to $7 \cdot 0$, and liver broth added plus a small quantity of oyster shell and steel wool, Professor L. D. S. Smith, personal communication), at $-20^{\circ} \mathrm{C}$. For this method an actively growing broth culture was used to inoculate scveral dozen egg brain media which were then incubated for two and a half hours before storage at $-20^{\circ} \mathrm{C}$. For use, one bottle was quickly thawed and used to inoculate $100 \mathrm{ml}$ of papain digest broth which was incubated at $37^{\circ} \mathrm{C}$ on a rotary shaker overnight. The organisms were subcultured once more for three to four hours before centrifugation and resuspension at a suitable density for immediate use. Viable counts were made on fresh blood agar plates as described by Bullen, Wilson, and Cordiner (1961).

\section{MICE}

Male or female mice of the TO strain (12-15 g) were used throughout.

\section{RON}

Iron was injected intraperitoneally at the rate of $5 \mathrm{mg} \mathrm{Fe} / \mathrm{kg}$ body weight in the form of ferric ammonium citrate $(0.07 \mathrm{ml}$ of $0.625 \%$ ferric ammonium citrate for a 12-15 g mouse). This dose was not toxic for mice, and Fe-treated controls were included with each experiment.

\section{PASSAGE OF PS. AERUGINOSA}

Each 'MP' passage consisted of four daily serial infections in mice, 15-20 mice being used in each group.

\section{Day 1}

Suitable dilutions of a centrifuged broth culture were injected intraperitoneally into approximately 20 mice. The majority of the animals were moribund after about 12 hours. The chief symptoms of infection were: the mice became hunched up, their fur was ruffled, and their eyes were encrusted. They moved slowly and in the terminal stages showed respiratory failure and paralysis of the hind limbs. Moribund mice were killed by cervical dislocation, and the spleen, which was usually enlarged and deep red, together with any peritoneal exudate, was removed aseptically and stored at $-20^{\circ} \mathrm{C}$.

\section{Days 2, 3, and 4}

Two spleens from the previous day's mice were homogenized in $3 \mathrm{ml}$ of broth saline, or phosphatebuffered saline, and a series of dilutions was prepared for intraperitoneal injection into the next group of mice. Spleens were removed from moribund mice as before. This procedure was repeated on days 3 and 4 .

\section{Day 5}

Two spleens were homogenized and plated out on fresh blood agar plates to check the identity and purity of the passaged strain. From these plates 20 colonies were selected at random and sown into $100 \mathrm{ml}$ of papain digest broth and incubated for three to four hours on a rotary shaker. This culture was used to inoculate egg brain media for storage of the passaged strain. These cultures were used once only for experimental purposes and were never used for further passage. All new passages were derived from the spleens of infected mice of the previous passage which had been stored at $-20^{\circ} \mathrm{C}$.

MEASUREMENT OF THE LD50 IN MICE Groups of five to 10 mice were injected intraperitoneally with $0.1 \mathrm{ml}$ of a suitable dilution of culture plus $0.1 \mathrm{ml}$ of phosphate-buffered saline, or $0.1 \mathrm{ml}$ of ferric ammonium citrate $(5 \mathrm{mg} \mathrm{Fe} / \mathrm{kg} /$ live weight). Each dilution of culture differed by $20 \%$, that is, $0.1 \mathrm{ml}$ per mouse for group $1,0.079 \mathrm{ml}$ for group 2, and so on, each dilution being made up to a volume of $0.1 \mathrm{ml}$ per mouse by diluent. In all the experiments the end point was taken at 48 hours and the results were analysed statistically (Finney, 1952 ) to give the $95 \%$ fiducial limits.

\section{Results}

The effect of the passage of Ps. aeruginosa in mice is shown in Table I and Figure 1. It is perhaps important to emphasize that each MP passage represents four serial cultures in separate groups of mice so that in the case of MP4 the culture had been serially passaged 16 times in individual mice. The reason for this procedure was to ensure that in each MP passage the organism had the opportunity of

\begin{tabular}{|c|c|c|c|c|}
\hline \multirow[t]{2}{*}{ Passage } & \multicolumn{2}{|l|}{ Normal Mice } & \multicolumn{2}{|c|}{ Iron-treated Mice } \\
\hline & LDSO Values & $95 \%$ Limits & LD50 Values & $95 \%$ Limits \\
\hline $\begin{array}{l}\text { Original } \\
\text { MP1 } \\
\text { MP2 } \\
\text { MP3 } \\
\text { MP4 }\end{array}$ & $\begin{array}{l}1.26 \times 10^{6} \\
2.86 \times 10^{6} \\
1.45 \times 10^{5} \\
2.63 \times 10^{4} \\
4.09 \times 10^{4}\end{array}$ & $\begin{array}{l}\text { Not done } \\
9.45 \times 10^{5}-4.77 \times 10^{6} \\
2.69 \times 10^{4}-4.22 \times 10^{5} \\
1.97 \times 10^{4}-3.24 \times 10^{4} \\
1.36 \times 10^{4}-7.94 \times 10^{4}\end{array}$ & $\begin{array}{l}4.74 \times 10^{5} \\
1.03 \times 10^{3} \\
1.9 \times 10^{2} \\
<10 \\
<10\end{array}$ & $\begin{array}{l}1.34 \times 10^{5}-1.67 \times 10^{6} \\
3.08 \times 10^{2}-2.79 \times 10^{3} \\
8.59 \times 10^{1}-2.61 \times 10^{2} \\
\text { Not done } \\
\text { Not done }\end{array}$ \\
\hline
\end{tabular}

Table I LD50 values and 95\% fiducial limits for the original culture of Ps. aeruginosa and subsequent passages 


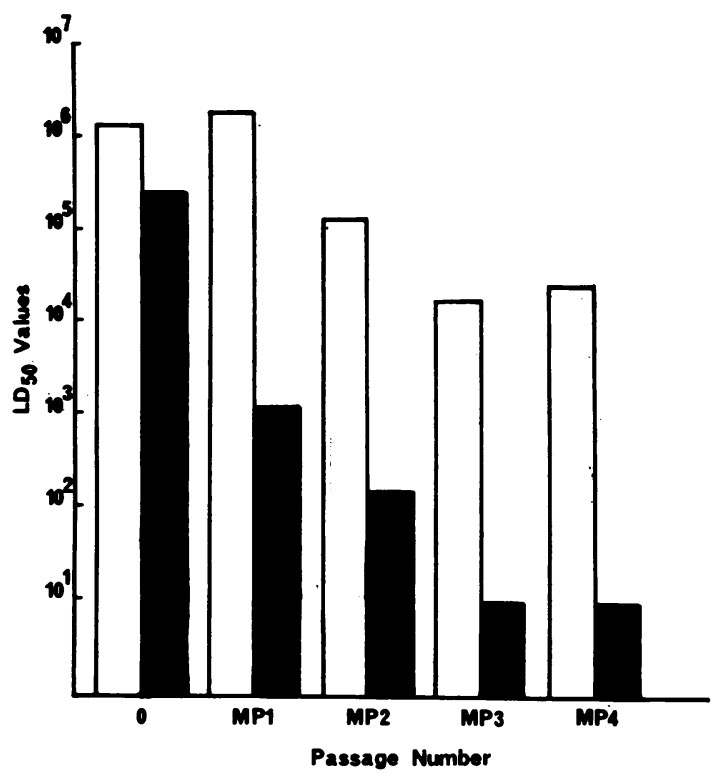

Fig. 1 Histogram of LDS0 values for the original culture and subsequent passages.

$\square$ Normal animals

Fe-treated animals

growing in mouse tissue for a reasonable length of time. Under these circumstances the LD50 fell from $1.2 \times 10^{6}$ for the original strain to $4.09 \times 10^{4}$ for MP4, an increase in virulence of nearly 100 fold. During the passage procedure it was also noticed that the length of time from injection to the appearance of serious symptoms decreased from 12 to 18 hours on the first day to five to six hours on day 4 . The morphology, antibiotic sensitivity, and production of pyocyanin of the original and passaged strains were frequently checked and compared. No apparent difference in these characters was found. Gel diffusion tests using trichloroacetic acid extracts (Muraschi, Bolles, Moczulski, and Lindsay, 1966) as antigens and a hyperimmune antiserum prepared in a horse against the original (unpassaged) culture showed two lines of identity between all the passages and no apparent extraneous lines.

The enhancing effect of iron on virulence is also shown in Table I and Figure 1. The effect on the original (unpassaged) strain was comparatively slight, the LD50 falling by a factor of 2 or less. However, the effect on the subsequent passages was very much greater, the LD50 being reduced by a factor of over a 1,000 fold in the case of MP3 and MP4. The combination of passage and treatment with iron thus had a very great effect on virulence and reduced the LD50 of the original strain by a factor of at least 100,000 fold.

\section{Discussion}

It appears that the factor or factors involved in the virulence of this strain of Ps. aeruginosa are relatively labile and may be enhanced by continuous bacterial growth within the host tissue and body fluids.

During the past two decades infections caused by $P s$. aeruginosa have increased in importance, especially among hospital patients. To quote but one example, Finland (1970) records that the percentage of cases of Ps. aeruginosa infection among cases of neonatal sepsis at the Yale New Haven Hospital was nil among 44 cases in $1933-43$ but rose to $21 \%$ in 62 cases in 1944-54, and to $15 \%$ in 73 cases in 1955-65. It may be argued that the appearance of this infection was probably related to the use of antibiotic therapy, but it also seems possible that accidental passage of this organism among susceptible patients in hospital might contribute to the emergence of virulent strains. Examples of transfer from patient to patient have been described by Shooter, Walker, Williams, Horgan, Parker, Asheshov, and Bullimore (1966).

The bacterial characters involved in the virulence of $P$ s. aeruginosa are largely unknown, but the fact that virulence is enhanced by iron compounds suggests that bacterial iron metabolism may play an important role Detailed discussions on the probable role of bacterial iron metabolism in resistance to infection are published elsewhere (Bullen, Rogers, and Lewin, 1971; Griffiths, 1971) but for the present purpose it may be useful to make the following points. Iron compounds, including ferric ammonium citrate, haemoglobin, and haematin greatly enhance the virulence of $E$. coli for young guinea pigs (Bullen et al, 1968). Similar results were obtained by Bornside, Bouis, and Cohn, (1968) with $E$. coli and haemoglobin in mice. Fletcher and Goldstein (1970) found that iron sorbital citrate greatly enhanced the growth of $E$. coli in the kidneys of rats with the production of a high proportion of kidney abscesses. Experiments in vitro have shown that both the bactericidal and bacteriostatic effects of normal rabbit serum on $E$. coli can be abolished by saturating the serum transferrin with iron (Bullen and Rogers, 1969). There is also evidence that saturation of the serum transferrin with iron does not interfere with complement fixation (Bullen, Rogers, and Lewin, 1971), which removes the objection that the effect of iron might be due to anticomplementary action. There is no evidence that iron compounds interfere with phagocytosis 
(Fletcher and Goldstein, 1970; Burrows, 1962; Bullen, Cushnie, and Rogers, 1967).

From the point of view of bacterial infections in man the importance of normal levels of transferrin are well illustrated by McFarland, Reddy, Adcock, Adeshina, Cooke, and Akene (1970) who found that children who died following treatment of kwashiorkor all had low levels of serum transferrin compared with those who survived. It is pointed out that oral or intramuscular administration of iron given in treatment could leave an appreciable concentration of free iron in the serum of those with low concentrations of serum transferrin. These authors also mention that children dying of kwashiorkor suffer from acute bacterial infections. This is supported by Hendrickse (1967) who found that children with marasmus or kwashiorkor had a heightened susceptibility to infection and to Ps. aeruginosa in particular.

In conclusion it seems reasonable to suppose that the possible enhancement of virulence of $P$ s. aeruginosa by passage from patient to patient might increase the seriousness of this infection. The further enhancement of virulence that occurs when serum transferrin is saturated with iron focuses attention on bacterial iron metabolism as a factor in pathogenicity. It also suggests that transferrin, which is normally unsaturated with iron, may play a significant role in resistance to infection.

We should like to thank Miss I. Robertson of the Statistical Services Section, NIMR, for doing the statistical analyses. Mrs C. M. Forsberg is an MRC scholar.

\section{References}

Bornside, G. H., Bouis, P. J., Jr., and Cohn, I., Jr. (1968). Hemoglobin and Escherichia coli, a lethal intraperitoneal combination. J. Bact., 95, 1567-1571.

Bullen, J. J., Cushnie, G. H., and Rogers, H. J. (1967). The abolition of the protective effect of Clostridium welchii type $\mathbf{A}$ antiserum by ferric iron. Immunology, 12, 303-312.

Bullen, J. J., Leigh, L. C., and Rogers, H. J. (1968). The effect of iron compounds on the virulence of Escherichia coli for guinea pigs. Immunology, 15, 581-588.

Bullen, J. J., and Rogers, H. J. (1969). Bacterial iron metabolism and immunity to Pasteurella septica and Escherichia coli. Nature (Lond.), 224, 380-382.

Bullen, J. J., Rogers, H. J., and Lewin, J. E. (1971). The bacteriostatic effect of serum on Pasteurella septica and its abolition by iron compounds. Immunology, 20, 391-406.

Bullen, J. J., Wilson, A. B., and Cordiner, K. (1961). The effect of normal and immune sera on the growth of Clostridium welchii type $\mathrm{A}$ in the allantoic cavity of embryonated hen eggs. J. Path. Bact., 82, 383-401.

Burrows, T. W. (1962). Genetics of virulence in bacteria. Brit. med. Bull., 18, 69-73.

Carney, S. A., and Jones, R. J. (1968). Biological and immunochemical properties of culture filtrates of virulent and avirulent strains of Pseudomonas aeruginosa. Brit. J. exp. Path., 49, 395-411.

Feingold, D. S. (1970). Hospital-acquired infections. New Engl. J. Med., 283, 1384-91.

Finland, M. (1970). Changing ecology of bacterial infections as related to antibacterial therapy. J. infect. Dis., 122, 419-431.

Finney, D. J. (1952). Probit Analysis, 2nd ed. Cambridge University Press, London.

Fletcher, J., and Goldstein, E. (1970). The effect of parenteral iron preparations on experimental pyelonephritis. Brit.J. exp. Path., $51,280-285$.

Forkner, C. E., Jr., Frei, E., III., Edgcomb, J. H., and Utz, J. P. (1958). Pseudomonas septicemia: observations on 23 cases. Amer. J. Med., 25, 877-89.

Griffiths, E. (19/1). Selective inhibition of macromolecular synthesis in Pasteurella septica by specific antiserum: a process reversible by iron. Nature (Lond.), Nature New Biol 232, 89-90.

Hendrickse, R. G. (1967). Interactions of nutrition and infection: experience in Nigeria. In Nutrition and Infection (Ciba Foundation Study Group No. 31), pp. 98-111. Churchill, London.

Klyhn, K. M., and Gorrill, R. H. (1967). Studies on the virulence of hospital strains of Pseudomonas aeruginosa. J. gen. Microbiol., 47, 227-235.

Lowbury, E. J. L., Thom, B. T., Lilly, H. A., Babb, J. R., and Whittall, K. (1970). Sources of infection with Pseudomonas aervginosa in patients with tracheostomy. J. med. Microbiol., 3, 39-56.

McFarlane, H., Reddy, S., Adcock, K. J., Adeshina, H., Cooke, A. R., and Akene, J. (1970). Immunity, transferrin and survival in Kwashiorkor. Brit. med. J., 4, 268-270.

Mowbray, J. F., Cohen, S. L., Doak, P. B., Kenyon, J. R., Owen, K., Percival, A., Porter, K. A., and Peart, W. S. (1965). Human cadaveric renal transplantation. Report of 20 cases. Brit.med.J., 2, 1387-94.

Muraschi, T. F., Bolles, D. M., Moczulski, C., and Lindsay, M. (1966). Serologic types of Pseudomonas aeruginosa based on heat stable 'O' antigens: correlation of Habs' (European) and Verder and Evans' (N. American) classifications. J. infect. Dis., 116, 84-88.

Rabin, E. R., Graber, C. D., Vogel, E. H., Jr., Finkelstein, R. A., and Tumbusch, W. A. (1961). Fatal Pseudomonas infection in burned patients: a clinical, bacteriologic and anatomic study. New Engl. J. Med., 265, 1225-31.

Rogers, H. J., Bullen, J. J., and Cushnie, G. H. (1970). Iron compounds and resistance to infection: further experiments with Clostridium welchii type $\mathrm{A}$ in vivo and in vitro. Immunology, 19, $521-538$.

Shooter, R. A., Walker, K. A., Williams, V. R., Horgan, G. M., Parker, M. T., Asheshov, E. H., and Bullimore, J. F. (1966). Faecal carriage of Pseudomonas aeruginosa in hospital patients: possible spread from patient to patient. Lancet, 2, 1331-1334.

Tinne, J. E., Gordon, A. M., Bain, W. H., and Mackey, W. A. (1967). Cross-infection by Pseudomonas aeruginosa as a hazard of intensive surgery. Brit. med. J., 4, 313-315.

Williams, R., Williams, E. D., and Hyams, D. E. (1960). Cross-infection with Pseudomonas pyocyanea. Lancet, 1, 376-379. 